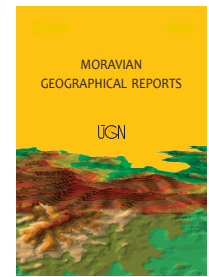

MORAVIAN GEOGRAPHICAL REPORTS

\title{
Tourism destination: The networking approach
}

\author{
Michał ŻEMŁA a *
}

\begin{abstract}
Different approaches to the analysis of tourism destinations as the basic units of research in tourism, are reviewed in this paper. Traditional geographical and economic perspectives are presented as the bases for more modern system and networking approaches. Network analysis is discussed as the most useful current approach to understand cooperation and coopetition processes taking place in destinations. This approach, developed in general management theory, however, if implicated directly in tourism, is not free from major problems and may lead to misleading conclusions. Among such problems, spatial embeddedness and the non-voluntary character of membership in a network, the crucial role of free goods in product creation, the predominance of SMEs in a destination network, differences between particular destinations and the difficulty in setting clear borders between networks, are discussed.
\end{abstract}

Key words: tourism destination, networking, destination governance, destination management

Article history: Received 17 December 2015; Accepted 25 July 2016; Published 31 December 2016

\section{Introduction}

Tourism destinations are "the fundamental units of analysis in tourism" (WTO, 2002). In its origin, the term 'tourism destination' is a typical geographical term and is understood as a part of geographical space. This approach is visible in the classic definition by Burkart and Medlik (1974, p. 46): "tourism destination is a geographical unit visited by tourists being a self contained centre". At present, even though it is one of the most commonly-used terms when analysing tourism phenomena, one cannot state that there exists a single, generally accepted definition or even approach to this term. As the subject of analysis of many different sciences, including human, social and life sciences, it started to be understood in many different ways. One cannot be surprised then that the approaches developed by sociologists, economists, regional and physical geographers, social geographers, etc. are different. Also, the models and approaches that are developed by particular sciences are becoming more and more sophisticated and thus, while they make it easier for specialists to achieve their research goals, at the same time they make it more difficult for researchers from different sciences to understand each other.

This paper aims to present the approach developed on the edge between economic geography and economic sciences, especially between management and the new institutional economics. The networking approach to tourism destination research is still perceived as a very promising way of understanding the term. The rules and tools developed by network analysis, however, cannot be simply transferred from management theory to the analysis of tourism destinations, for several reasons. The presentation of those reasons, at least those which were selected and postulated to be the most important ones, creates the content for the discussion part of the paper. Even though the paper is focused on the approach that is very suitable for economic geography and economic analysis, it should be kept in mind that the tourist destination is still a multidisciplinary issue. If a multidisciplinary approach is not applied to this topic, the analysis and conclusions will be unbalanced. The demand side approach derived from consumer psychology, which is difficult to be inserted into the network approach, in particular is extensively presented here as an attempt to avoid this kind of imbalance. The paper has a typical theoretical character in which the aims are reached by a literature review, the comparison of different approaches, and a discussion of the conclusions found in secondary sources.

\section{The definition of the tourism destination concept}

\subsection{Classic spatial approaches}

One of the most influential definitions of a tourism destination is the one given by Goeldner and Ritchie (2003, p. 466) in their world-wide recognised textbook, which states that "tourism destination is a particular geographic region within which the visitor enjoys various types of travel experiences". Other definitions that underline the spatial

\footnotetext{
${ }^{a}$ Department of Tourism and Regional Studies, Institute of Geography, Pedagogical University in Cracow, Poland (*corresponding author: M. Żemła, email:michalzemla@up.krakow.pl)
} 
nature of tourism destinations are those by Murphy (1985, p. 7), Gonçalves and Águas (1997, p. 12) or Burkart and Medlik (1974) cited above in the Introduction (see also Tab. 1). One of the most detailed definitions within this classic approach is the one given by Framke (2001, p. 5), which states that "tourism destination is a geographical area, which contains landscape and cultural characteristics and which is in the position to offer a tourism product, which means a broad wave of facilities in transport - accommodation - food and at least one outstanding activity or experience." Finally, the definition given by Seaton and Benett (1997, p. 351), who were focused not only on the physical features of the place but also on intangible characteristics, is worth underlining. The last two definitions open new opportunities and a new approach which is much more connected with the achievements of economic geography and/or economics.

\subsection{Economic geography and economics approaches}

Economic geographers, following achievements of the economic sciences, often perceive a tourism destination not only as part of geographical space but also as an important element of the tourism market which can be described by features of tourism demand and features of tourism supply. Similarly, within economic approaches to the analysis of tourism destinations, two main attitudes might be pointed out (Ewing and Haider, 2000, p. 56). The supply side approach is developed both by economic geographers and economists, while the demand side approach is more typical for the economic sciences. In approaches typical of the demand side analysis, particular tourism destinations are still perceived subjectively. Hu and Rithie (1993, p. 25) state that a tourism destination "reflects the feelings, beliefs and opinions that an individual has on destinations and see the ability to ensure satisfaction with his holiday special needs". This approach is focused on the perceptions of particular (both past, current and future) tourists and their market choices. Destination is here a function of the tourists' choice - a place or region where tourists choose to go (Flagestad, 2002, p. 3). In this approach, a tourism destination can be a perceptual concept, which can be interpreted subjectively by consumers, depending on their travel itinerary, cultural background, purpose of visit, educational level and past experience (Buhalis, 2000). This leads to the conclusion that a destination is not just something that actually exists - it is also what is thought to exist, a mental concept in the minds of its tourists and potential tourists (Seaton and Bennett, 1997). This approach, focused on a consumer and his/her perceptions, is a cornerstone of modern tourism marketing. Among the attitudes most commonly used here, regarding tourism destinations as brands available for tourists and being alternatives in their choices (Konečnik and Ruzzier, 2006, p. 2; Hosany, Ekinci and Uysal, 2007, Dawes, Romaniuk and Mansfield, 2008), is very common. According to many researchers (Morgan, Pritchard and Pride, 2002; Pike and Page, 2014) destinations have emerged as the largest brands in the travel industry.

The theory of a destination choice based on a division of available destinations into decision sets - like the process seen on other markets - was developed as long ago as in the 1970s by Woodside (Woodside and Sherrell, 1977; Woodside and Lysonski, 1989). In this sense, particular tourism destinations are competing for being chosen by a tourist. The metaphor of a tourism destination as a brand allowed researchers to introduce into tourism destination practice the many achievements of corporate marketing and management (Hankinson, 2004; Kozak, 2004; Żemła, 2010a). This subjective perception of the boundaries of a destination is in line with a view looking for definitions of a region (of any kind, not necessarily the tourist one) in social consciousness (Paasi, 2001; Chromý, Kučerová and Kučera, 2009; Semian, 2012). This approach now gains more and more attention among social geographers.

The demand side approach, which is very useful in marketing analysis and strategies and in the description of competition between destinations, also has some limitations. The subjectivities in the perception of particular destinations and their boundaries, makes analysis and management processes very difficult. This incoherence between the demand side approach and the supply side approach, which is focused on internal processes, comprises one of the largest contemporary challenges for destination marketers. Particular marketing actions are usually financed by a single entity or a group of entities located inside some kind of boundaries, especially administrative boundaries, as public administrations are often involved. Those administrative boundaries, however, are often not perceived by tourists who have their own, usually subjective, image of the destination they chose to go to. As a result, tourists may receive a leaflet that promotes to them an administrative region and they do not even know where it is located. This is exactly what happens when German tourists at ITB ('Internationale Tourismus-Börse') fairs are given brochures that invite them to Polish administrative regions, i.e. voivodeships

A different perspective is accepted when defining a tourism destination from a supply side approach. Here, a tourism destination is most commonly understood as an area of the existence and/or concentration of tourism demand, tourism supply and their consequences, including economic, social, environmental and other consequences. This makes this approach useful also for physical geographers and even for sociologists. The supply side approach, however, is not homogenous. The basic definitions are focused on the analysis of particular phenomena that are visible in tourism destinations. This is often the development of tourism companies and tourism infrastructure, as in the definition by d'Angella and Sainaghi (2004, p. 38) who understand a tourism destination as "a geographic area where there is a concentration of small/medium- sized companies sharing a homogeneous background". A similar attitude can be found in the given by Bordas (1994, p. 3), who describes a tourism destination as "a group of tourist attractions, infrastructure, equipment, services and organisations concentrated in a limited geographical area". A more complex definition is offered by Elmazi, Pjero and Bazini (2006, p. 2). In their view, "destination represents a spatial unity of the tourism offer, possessing the appropriate elements of the offer, being market-oriented, as well as tourist-oriented, existing independent of administrative boundaries, requiring management. It provides the fundamental institutional framework for formulating a concept of tourism development in which the focus is shifted from the accommodation facility to the entire surrounding area together with its economic structure (town, region, zone, country)."

A tourism destination in the supply side approach is often perceived within the prism of its products. Destination is regarded here as an "area which consists of all services and offers a tourist consumes during his/ her stay" (Bieger, 1998, p. 7) or an "amalgam of tourism products offering an integrated experience to consumers" (Buhalis, 2000, p. 97). Other researchers (Seaton and 


\title{
SPATIAL APPROACH
}

Both physical entity (a geographical location with spatial, physical properties), but it is also a more intangible socio-cultural entity (made up of history, its people, its traditions and way of life)

Geographical unit visited by tourists being a self-contained centre

Seaton, Bennett, 1997, p. 351

An area (region or place) that possesses several natural resources or man-made attractions that attract tourists

Area with different natural and/or human made features, which attract non-local visitors (or tourists) for a variety of activities

Geographical area, which contains landscape and cultural characteristics and which is in the position to offer a tourism product, which means a broad wave of facilities in transport - accommodation - food and at least one outstanding activity or experience

A particular geographic region within which the visitor enjoys various types of travel experiences

Burkart, Medlik, 1974, p. 46

Gonçalves, Águas, 1997, p. 12

Murphy, 1985, p. 7

Framke, 2001, p. 5

Goeldner, Ritchie, 2003, p. 466

A place where travellers choose to stay awhile for leisure experiences, related to one or more features or characteristics of the place - a perceived attraction of some sort

Leiper, 2004, p. 128

A certain geographic area which contains tourism products that motivate visiting tourists and Koestantia, et al. 2014, p. 1141 encourage tourism activities

Traditionally treated as a well-defined geographical area but it can also be viewed as a product or a brand Tan, et al., 2013, p. 623

\section{ECONOMIC APPROACH}

\section{Demand side approach}

A tourism destination "reflects the feelings, beliefs and opinions that an individual has on destinations and see the ability to ensure satisfaction with his holiday special needs"

A destination is not just something that actually exists; it is also what is thought to exist, a mental concept in the minds of its tourists and potential tourists

Destination is a function of tourists' choice - a place or region where tourists choose to go

Destination can be a perceptual concept, which can be interpreted subjectively by consumers, depending on their travel itinerary, cultural background, purpose of visit, educational level and past experience

The destination as a geographic area (place or region) is determined by guest's needs concerning Pechlaner, 1999 , p. 336. accommodation, catering and entertainment, and not primarily by local conditions and situations

Defined as a region where tourists choose to travel outside of their place of residence

A tourist destination is a situation or place where a tourist himself takes into account travelling there and visiting its attractions with his own special motivations. This situation in terms of geography can range from a limited historic or archaeological site to the geographical area of a country or even a set of countries

\section{Supply side approach}

Destination represents a spatial unity of the tourism offer, possessing the appropriate elements of the offer, being market-oriented, as well as tourist-oriented, existing independent of administrative boundaries, requiring management. It provides the fundamental institutional framework for formulating a concept of tourism development in which the focus is shifted from the accommodation facility to the entire surrounding area together with its economic structure (town, region, zone, country)

Geographic area where there is a concentration of small/medium-sized companies sharing a d'Angella, Sainaghi, 2004, p. 38 homogeneous background

Destination can be regarded as a combination (or even a brand) of all products, services and ultimately experiences provided locally

The geographic area to which a tourism policy applies

Hu, Rithie, 1993, p. 25

Seaton, Bennett, 1997, p. 351

Flagestad, 2002, p. 3-1.

Buhalis, 2000, p. 97.

Mariutti, et al., 2013, p. 13.

Izadi, Saberi, 2015, p. 147.

Elmazi, et al., 2006, p. 2.

\author{
d'Angella, Sainaghi, 2004, p. 38
}

Buhalis, 2000, p. 98.

Goeldner, Ritchie, 2003, p. 466

An area which is separately identified and promoted to tourists as a place to visit and within which the tourist product is co-ordinated by one or more identifiable authorities or organisations

A particular geographic region within which the visitor enjoys various types of travel experiences

Capone, Boix, 2003, p. 1

Goeldner, Ritchie, 2003, p. 466

Bornhorst, et al., 2010, p. 572

The geographical region which contains a sufficient critical mass or cluster of attractions so as to be capable of providing tourists with visitation experiences that attract them to the destination for tourism purposes

A target area in a given region for which a significant offer of attractions and infrastructure of tourism are typical. In a broader sense these are countries, regions, human settlements and other areas that are typical with their high concentration of tourists, developed services and other tourist infrastructure, the result of which is a great long-term concentration of visitors

Tab. 1. Selected definitions and approaches to define a tourism destination Source: author's elaboration, based on literature cited 


\section{MANAGERIAL APPROACH}

\section{Destination as a product}

Destination is the central tourism product that drives all others. It is one product but also many (Seaton Seaton, Bennett, 1997, p. 351 1997, s. 350-351)

Mosaic of different elements (products) with different life cycles.

Gonçalves, Águas, 1997, p. 12

Area which consists of all services and offers a tourist consumes during his/her stay.

Bieger, 1998, p. 7.

Amalgam of tourism products offering an integrated experience to consumers

Buhalis, 2000, p. 97.

Destination can be regarded as a combination (or even a brand) of all products, services and ultimately Buhalis, 2000, p. 98. experiences provided locally

A destination can be regarded as the tourist product that in certain markets competes with other Bieger, 1998, p. 7. products

\section{A firm as a metaphor of a destination}

A collective producer in a firm-like structure co-ordinating complementary services according to needs Flagestad, 2002, p. 3-2 and preferences of target market-segmented and marketed as one unit under one brand

Because the markets linked to the products are quite stable, destinations may be seen as strategic Bieger, 1998, p. 7 business units from the management point of view

Process-oriented units of competition, which must be able to provide products and offers for defined Pechlaner, 1999, p. 336. target groups and guest segments

\section{SYSTEMS APPROACH}

Tourism firms creating economic and jobs effects are part of a bigger totality, where it is not the service offer of single firms but all service offers together, that are the sale argument. This totality is in the literature called a destination. Destination can be described as a system containing of three resource bases: the attraction bases, the facility bases, and the market base

A place considered as a system of actors that co-operates in order to supply an integrated tourist product

Capone, Boix, 2003, p. 2

System containing following subsystems: entrepreneurial systems, public self-government systems, Elmazi, et al., 2006, p. 2 . other systems

Defined as an area bound to no administrative limitations within which tourist aspects are interrelated and integrated in a systemic manner that drives travel motivations, visits, and the industry mechanism

Koestantia, et al., 2014, p. 1141

\section{NETWORK APPROACH}

Destination typically consist of a number of individual enterprises offering "their" product in a Flagestad, 2002, p. 3-2 relatively non-coordinated way

A place considered as a system of actors that co-operates in order to supply an integrated tourist product Capone, Boix, 2003 , p. 2.

A group of tourist attractions, infrastructure, equipment, services and organisations concentrated in a Bordas, 1994, p. 3.

limited geographical area

Destinations are considered as complex systems, represented as a network by enumerating the stakeholders composing it and the linkages that connect them. (...) A tourism destination shares many of these characteristics, encompassing many different companies, associations, and organisations whose mutual relationships are typically dynamic and nonlinear

\section{Tab. 1: continued}

Bennett, 1997, p. 351) underline a destination as not only a place where tourism products are offered but also as the central tourism product that drives all other products. It is also not clear if a destination should be perceived as a single important product offered on the tourism market or as a pack of products offered locally. Seaton and Bennett (1997, p. 351) state that a tourism destination "is one product but also many", which underlines the duality of the nature of this concept. Perceiving a destination as a product, i.e. an offer for tourists to spend their time, is much closer to the demand side approach as it returns to customers' perceptions and to competing for what they choose. On the contrary, considering a destination as a pack of products is closer to the supply side approach. This reflects the fact that a destination's product might be targetted to different segments at the same time that offers different ways of spending time in the same place. In that sense, local offers for active tourists, for culture lovers or spa and wellness lovers, might be perceived as different products of a destination and the task for destination managers is then managing the product portfolio. This kind of portfolio management is, however, to some extent different than in companies as particular products cannot be treated separately. Tourists' motivations are much more complicated than just participating in one form of tourism, and often during their stay at a destination, apart from the activity that is their main motivator, they might undertake other activities. Additionally, some local offers might be common for participants of different forms of tourism, which means particular products have common parts. Often accommodation facilities used by different tourists might be illustrations of such a common part. 
The views presented above are typical for economists and/ or economic geographers. Within the economic sciences, however, the concept of tourism destination also became the subject of interest for management studies. A tourism destination can be considered as the most important unit of management applications in tourism (D'Angella and Go, 2009). Usually, researchers who represent management science also define a tourism destination in a supply side approach, but the stress is put on management process and structures. This approach is more complex and part of it remains controversial as tourism destinations cannot be regarded as formal organisations and no formal hierarchical structures exist. This is because a destination typically consists of a number of individual enterprises that offer "their" product in a relatively non-coordinated way (Flegestad, 2002, p. 3).

The chaotic, non-coordinated development of tourism supply, however, can be replaced by the cooperation activities of particular entities, which is pointed out by Capone and Boix (2003, p. 2). A destination is perceived then as "a collective producer in a firm-like structure coordinating complementary services according to needs and preferences of target market segmented and marketed as one unit under one brand" (Flagestad, 2002, p. 3). As a result, Pechlaner (1999, p. 336) defines it as a "processoriented unit of competition, which must be able to provide products and offers for defined target groups and guest segments". The metaphoric presentation of a destination as an entity similar to a company was required in order to implement a rich variety of tools "borrowed" from the area of corporate management, which is much better developed. It soon turned out, however, that although destinations have to compete on the tourism market in a very similar way to how companies compete, but as specific market entities that are not even being a formal organisation, destinations have so many and so strong characteristic features that a simple implementation was not required and sound adjustment was necessary. Among other things, the adjustment included perceiving a destination as an entity similar to a strategic business unit (SBU) of a diversified company rather than as a company itself. A place (region, city, country etc.) is also diversified in what its activities are and products offered on internal and external markets, as well as tourism, is just one of those activities/products as an SBU is in a diversified company. This way of thinking is found in the definition as cited by Pechlaner, but it can also be found in the works by Gnoth (2004) or Bieger (1998).

\section{The network approach to tourism destinations}

With the further development and the joint use of spatial and economic supply side definitions of tourism destinations, more sophisticated approaches could have been constructed, especially the systems and networking approach. In the systems view, a destination is defined as an area bound to no administrative limitations, where tourist aspects are interrelated and system-integrated. This has impacts on travel motivations, visits, and the industry mechanism (Koestantia, Nuryanti, Suwarno, Prayitno, and Femina, 2014). According to Elmazi, Pjero and Bazini (2006, p. 2), this system contains the following subsystems: entrepreneurial systems, public self-government systems, and other systems; however, this view might be too simplified, as the number of subsystems might be bigger and their relations might be more complicated. The development of the systems approach that analyses the complexities of tourism destinations, opened up new opportunities for establishing a modern network approach to destinations. This approach was possible due to some kind of evolution which took place in the major sciences adapted to tourism destinations analysis at the beginning of the century. The network approach gained more and more attention in sociology, economics, management studies, and regional and economic geography.

One of the main features of tourism destinations is that there are no hierarchical ties between the numerous entities that offer products independently. This is what makes contemporary researchers discuss effective coordination and/or governance rather than management (Baggio, Scott and Cooper, 2010a; Beaumont and Dredge, 2010; Paget, Dimanche and Mounet, 2010; Ruhanen, Scott, Ritchie and Tkaczynski, 2010; Cohen and Cohen, 2012). The existence and market effectiveness of destinations on the ground of management theories could be better understood, since market structures were further developed and the theories that followed them were further developed. In the contemporary world, numerous definitions are used to set the borders of companies. According to a new paradigm in strategic management based on inter-organisational relations (IR) (Doz and Hammel, 1998; Gulati, Nohria, and Zaheer, 2000; Barringer and Harrison, 2010), companies started to search for sources of their competitive advantage in non-competitive relations with other entities, including competitors. With its origins in sociology (Galaskiewicz, 1985; Galskiewicz and Wassermann, 1994), the networking theory (NT) started to be used in management studies (Provan, Fish and Sydow, 2007). This theory was also found to be very useful to better describe and understand processes that take place in tourism destinations. In contemporary research of tourism destinations, the networking approach is used more and more often.

According to a simple and general definition, a 'network is a set of items, which we will call vertices or sometimes nodes, with connections between them, called edges' (Newman, 2003, p. 167). In the business context, Hall (2005, p. 179) defines a network as 'an arrangement of interorganisation cooperation and collaboration'. There exist many different approaches and methods inside NT, however, which might be and were introduced into tourism destinations analysis, which result in substantial problems in establishing a coherent theory of destination networking (Van der Zee and Vanneste, 2015).

The theoretical literature on IR is fragmented, with several disciplines contributing to the field. Tourism researchers who attempt to implement it into tourism destination research point out several theories or microtheories, which might be valid (Beritelli, Bieger and Laesser, 2007, p. 97). Transaction costs, resource dependence theory and networking theory are cited most often (Beritelli, Bieger and Laesser, 2007; Wang, Xiang, 2007). The last one seems to be a particularly promising option when analysing the tourism market as tourism might be described as a network industry par excellence (Scott, Cooper and Baggio, 2008). Support for this claim is found in the definition of tourism as a system, where interdependence is essential (Mill, Morrison, 1985; Leiper, 1990; Bjork and Virtanen, 2005; Lazzeretti and Petrillo, 2006) and collaboration as well as cooperation between different organisations within a tourism destination create the tourism product (Pechlaner, Abfalter and Raich, 2002; Fyall and Garrod, 2005). In 
this way, local alliances, agreements and other formal and informal governance structures help to compensate for the fragmented nature of a tourism destination (Scott, Cooper and Baggio, 2008).

NT has been suggested as a way to better understand ongoing marketing activities and processes aiming to develop a business (von Friedrichs Grängsjö, 2007). Buhalis (2000) indicates that most destinations consist of networks of tourism suppliers and that the benefits of such networks include a more profitable tourism destination. Within NT, a tourism destination may be considered as a cluster of interrelated stakeholders embedded in a social network (Scott, Cooper and Baggio, 2008). Such a network of stakeholders interacts, and jointly meets visitor needs and produces the experience that the travellers consume. These destination stakeholders include accommodation businesses, tourist attractions, tour companies, and other companies that provide commercial services, government agencies and tourism offices, as well as representatives of the local community. Interaction between these stakeholders is complex, dynamic, and subject to external shocks. The basic premise of tourism destination management is that through cooperative planning and organisational activities, the effectiveness of these joint interactions can be improved to the benefit of individual stakeholders (Baggio, Scott, Cooper, 2010a).

One reason for the study of networks as a central part of tourism is that they form a basis for collective action. In tourism, many of the main resources of a tourism destination are community "owned" and are used jointly to attract tourists. These may be physical resources such as beaches, lakes, scenic outlook and national parks; built resources such as museums, art galleries and heritage buildings; or intangible resources such as destination brands or the reputation of the friendly attitudes of local people. Such collective action does not necessarily require a network organisation, but if resources are generally missing and if decisions concerning tourism are not often seen within the government mandate, the response is often a network of the stakeholders involved (Scott, Cooper and Baggio, 2008). Also networks are suggested to function as systems which can organise and integrate tourism destinations, making the firms involved benefit, enhance destination performance and quality, as well as stimulate providing "wholesome and memorable experiences' for tourists (Zach and Racherla, 2011, p. 98).

As the networking approach was found to be useful for business practice and studies, at the same time another process took place. This process enhanced the networking view of tourism destinations. Within human geography, a new network approach to 'place' was developed. Nicholls (2009) describes two different approaches: the relational conception of place, and territorial conceptions of place. Both examine social relations in distinct locations but they emphasise different aspects of these relations: the former emphasises the structured cohesion of relations in particular sites, while the latter highlights the contingent interactions of diverse (in terms of sociology and geography) actors. While supporting the relational conception of place, Amin and Thrift (2002, p. 72) argue that places are areas where actors with different statuses, geographical ties and mobilities interact in fleeting and unstructured ways. In this view, place has particular qualities that influence social networks that emerge within it. On the one hand, proximity and stability associated with a particular place create favourable conditions for strong-tie relations. Additionally, a particular place is made up of a number of contact points where diverse actors can come into regular interactions with one another (Nicholls, 2009, p. 91).

Among the earliest attempts to present a tourism destination in a network perspective, works that analyse destinations as clusters might be pointed out (Nordin, 2003; Weiermair and Steinhauser, 2003; Hawkins, 2004; Jackson and Murphy, 2006). Industry clusters exist where firms and organisations are loosely geographically concentrated or an association of firms and organisations is involved in a value chain producing goods and services, and they are innovative (Enright and Roberts, 2001, p. 66). Initially, benefits of industrial agglomeration resulted from natural resources, the spatial costs of external transactions (Scott, 1983), transport organisation and costs (Scott, 1986, Scott and Storper, 2003), labour or economies of scale (Enright, 2003). According to Porter (1990), clusters are geographic concentrations of interconnected companies, specialised suppliers, service providers, firms in related industries, and associated institutions (e.g. universities, standards agencies, trade associations) in a particular field that compete but also cooperate. Porter's view that underlying competition and cooperation between companies within a cluster and searching for competitive advantage in an economy in innovations and an instant search for development (Porter, 1990), gave a new impetus to the cluster concept. His cluster theory has become the standard concept in the field, and policy-makers from all over the world have seized upon Porter's cluster model as a tool for promoting national, regional and local competitiveness, innovation and growth (Martin and Sunley, 2003, p. 5).

According to many authors, regional clustering is part of a new industrial order (Hospers and Beugelsijk, 2002; Marková, 2014) and can be interpreted as part of the sub-national or global innovation and production system (Guinet, 1999). At present, the cluster concept focuses on knowledge transfer (Maskell, 2001), as well as on linkages and interdependencies among actors in value chains. It goes beyond the traditional ideas on clusters, which involved horizontal networks of firms operating on the same endproduct market in the same industry group (Enright and Roberts, 2001). Especially when accepting modern definitions of clusters in which the cooperation between companies is underlined (Nordin, 2003), many similarities can be seen between the ways in which destinations and clusters operate. In both cases, the role of public authorities is acknowledged. For tourism destinations, however, this function is wider than just the creation of good conditions for the companies to develop, as the public sector is also responsible for delivering many important elements of a tourism destination product. The most important difference is seen in the sequential nature of product creation in such industrial clusters as Silicon Valley, the Italian fashion cluster or the forestry cluster in Sweden (Porter, 1998). A cluster is usually formed by a chain of suppliers and industrial customers with a visible single company (or together with several similar competing companies), which is responsible for a final product and for selling it to the final customer.

Even taking into the consideration the fact that in a cluster there are usually many different products that are produced and that almost all of them are offered by a different type of company, this is not similar to what can be seen in a tourism destination: all network members produce only a part of the 
service potential that covers a wide scope of offers, and the final customers, i.e. visitors, build a product for themselves. The too simple implementation of the cluster concept into tourism research was also criticised as being too businessoriented and for disregarding the fact that cluster members such as tourism companies - are usually unable to produce by themselves the reasons for tourists to come. This role is usually played by tourism goods, which often are free goods, and cluster implementation might result in marginalisation of their impact (Hassan, 2000). This special status of free goods, which are elements of comparative advantage and understood this way by Porter (1990) and followers (Hill and Brennan, 2000; Nordin, 2003; Tallman, Jenkins, Henry and Pinch, 2004) as less important in making an economy competitive, underlines the need for implementing geographic and spatial approaches (Scott and Storper, 2003; Scott and Garofoli, 2007; Asheim, Cooke and Martin, 2008) to industry agglomeration in tourism destinations. Hence, typically business-oriented approaches rooted in Porter's theory are not sufficient to explain the phenomena of clustering tourism destinations. Several researchers thoroughly discuss other similarities and differences between industry clusters and tourism destinations (Simpson and Bretherton, 2004; da Cunha and da Cunha, 2005; Jackson and Murphy, 2006; Feng and Miao, 2009).

Another concept developed in regional economics and economic geography and applied to tourism destinations analysis is the industrial district. Industrial district theory started in the late nineteenth century with the work of Marshall (1898), who was trying to explain the localisation (geographical concentration) of English industries such as pottery, cutlery and basket making (Becattini, 2002b). Then, in the late 1970s, the theory of industrial districts was applied to an area in Italy which became known as the 'third Italy' (Pyke, Becattini and Sengenberger, 1992). These regions seemed to be growing faster than the rest of the country and coming out of recessions more successfully. From that point on, the concept remains particularly popular among Italian scientists (Becattini, 2002a; Becattini, 2002b; Corň and Grandinetti, 2001; Sforzi, 1989).

According to Mottiar and Ryan (2006), industrial districts are characterised by geographical and sectorial concentration of firms, small size companies, strong interfirm relations, a social or professional milieu, and a stress put on innovations. Similarly, Hjalager (2000) perceives the following main features of industrial clusters: the interdependence of firms, flexible firm boundaries, cooperative competition, trust in sustained collaboration and a "community culture" with supportive public policies. A very simple definition of an industrial district was given by Corň and Grandinetti (2001, p. 189), stating that this is a network of small- and medium-sized enterprises embedded in a local context, turns our attention to the networkshaped nature of industrial districts. All of these statements show that the concept of industrial districts deals with similar phenomena as clusters and, like the cluster, the concept might be implemented in tourism destinations analysis. According to Hjalager (2000) and Mottiar and Ryan (2006), tourism destinations might be treated as illustrations of industrial districts. This concept, however, is not as popular as clusters among tourism researchers. This might be due to the focus on production sectors by the core theory of industrial districts (Mottiar and Ryan, 2006). Also the comparability between tourism destinations and industrial districts is less obvious, especially with respect to governance structures. This is also true for the intensified vertical division of labour between regions that provide services to tourists and regions that provide these services (Hjalager, 2000).

Another attempt to implement the approach typical for NT to tourism destinations analysis is Gnoth's metaphor of virtual service company, which might be defined as a network of enterprises that are using resources jointly and which organise their cooperation as a joint effort (Gnoth, 2004). As Gnoth (2004) points out, however, there are also important differences between the typical virtual firms found most commonly in industrial markets, and tourism destinations. Firstly, in tourism destinations, usually there is no focal company in charge of the overall management of the production process. Secondly, the contribution of each small- and medium-sized enterprise (SME) in tourism is not cumulative as is the case, for example, with the contribution of different companies in the motor industry. Tourism is experienced rather holistically and often the customer value is not derived directly from particular services but is created between the various services, as a combination of those services and the tangible and intangible assets of a given destination (Gnoth, 2004).

Probably the most complex proposition of how to analyse tourism destinations in the framework of NT is the one offered by Scott, Cooper and Baggio (2008). Sophisticated quantitative methods are implied here to better understand relations between particular stakeholders and their influence on the effectiveness of the whole network.

Currently, NT is most commonly used to better understand governance in tourism destinations. In the network approach, understood here as in opposition to the corporate approach (Ruhanen, Scott, Ritchie and Tkaczynski, 2010), governance might be defined as "the self-organising interorganisational networks characterised by interdependence, resource exchange, rules of the game and autonomy from the state" (Rhodes, 1997, p. 15). Governance, however, is a concept which refers to relationships between multiple stakeholders and to how they interact with one another. It involves the issue of how the stakeholders determine, implement and evaluate the rules of interaction (Baggio, Scott, Cooper, 2010a, p. 51). According to Beritelli, Bieger and Leasser (2007, p. 96) the concept of governance applied to tourist destinations consists of setting and developing rules and mechanisms for a policy, as well as business strategies, by involving all the institutions and individuals. Similarly, Nordin and Svensson (2007) focus on social networks and relationships, with emphasis on those between the public and private sectors. It has been noted that the public and private sectors are involved, and as a result, the governance dimensions applied may be derived from those used in both sectors (Ruhanen, Scott, Rithie and Tkaczynski, 2010, p. 5). The whole concept of destination governance is based on making the groups of organisations that cluster together to form a destination context (Nordin and Svensson, 2007).

\section{Special challenges in implementing NT in the area of tourism destinations}

A tourism destination is very often perceived as a network of stakeholders by researchers. The image of a destination presented in the frame of NT makes it easier to better understand the processes and phenomena that might be seen in destinations. The implementation of NT in tourism, however, is not free from traps and difficulties. Among them, spatial embeddedness and the non-voluntary nature of 
membership in a network, the crucial role of free goods in product creation, the predominance of SMEs in a destination network, differences between particular destinations and the difficulty in setting clear borders between networks, will be discussed here as the most important ones. Each of them may become more important if the methods and tools of analysis are implemented directly from other, especially industrial, markets (Żemła, 2010b).

\subsection{Spatial embeddedness and the non-voluntary nature of membership in a network}

One of the most prominent questions which have to be answered by a company with respect to NT is whether to enter the network or not (Möller and Svahn, 2003). In NT, a company is usually free in choosing the network it is going to join or whether to join any network at all. Tourism companies in destinations do not have such a choice. Regardless of whether they are willing to collaborate in the network, they are interlinked with other entities involved in the destination product preparation. This spatial embeddedness changes radically the rules of cooperation. According to NT, a company which is disappointed by the results of its network membership, might leave and search for other partners. This decision is more or less difficult to take - but it can be taken. In a destination, tourism companies are somehow "condemned" to cohabitation. A company cannot "escape" from its partners if they behave in a hostile manner or are irresponsible, and it cannot "escape" from a network if it is inefficiently organised and managed. A company, even if it does not regard itself to be a network member and does not collaborate actively with other entities, is under the influence of the network actions and other companies' actions, as well as the network itself is influenced by this company.

\subsection{The crucial role of free goods in product creation}

One of the biggest challenges in understanding relations in networks in tourism destinations is the fact that the tourist experience is derived from the 'between' of services of particular local companies, rather than directly from those services. The key factors for visitors are often the natural or cultural resources of the place that are still free goods. The very first problem which has to be underlined by this statement is the role of the public sector in tourism product creation (Flagestad, 2002). Future research should include answers to the question of what are the consequences of the fact that the external resources used by tourism companies are rather free resources which can be used simultaneously by many companies, whereas resource dependency theory underlines mostly the possibility to use the external resources that belong to other companies, especially the resources which are not available for other competitors. In the research by Albrecht (2013), it was found that substantial progress has been made in the investigation of private sector networks at the destination levels, but the research on networks involving public sector stakeholders and networks across sectors and levels of governance remains insufficient. Establishing a research approach that allows one to consider the public sector as a holder of free resources and the relations between local actors and free resources, seems to be one of the most important tasks for tourism researchers who look for methods to implement the NT into the field of tourism destination.

Free goods in the destination context are not only tangible goods, however, they are also marketing assets. The tourism destination brand and its attractiveness are among the main factors that influence success by the local companies.
In that case, the problem of the so-called freeriders, i.e. the stakeholders who benefit from the efforts made by other stakeholders without their own effort, remains an important issue (Zmyślony, 2009).

\subsection{The predominance of SMEs in a destination network}

There is much evidence in the literature that tourism is a small- and medium-sized enterprises (SMEs) dominated industry (Go and Appelman, 2001; Woods and Deegan, 2003; Jones and Haven-Tang, 2005). Additionally, a lot of literature on the NT is concerned with large companies' collaboration, which is the reason why the rules described there are not fully relevant to the SMEs-dominated tourism sector. There are several consequences of the dominance of SMEs in tourism destinations. On one hand, the SMEs sector should be particularly interested in collaborating as this might weaken their market constraints resulting from their size and from limited financial resources (Go and Appelman, 2001, p. 193). A micro-firm like a family company from the accommodation business might be promoted world-wide because of its participation in the destination network. This is just one example of possible benefits.

On the other hand, the SMEs dominated industry causes many difficulties and constraints in cooperation and network formation. Most of them are entities which are or should be included in a network. The more companies that are involved in a network, the more difficult is its management, especially for setting common goals for the network as a whole. Competitive relations between SMEs and their different profiles (e.g. the different services and goods that companies offer visitors) make setting the goals even harder. Smallscale operations are usually also the reason why the level of intangible resources, especially knowledge, is very low. This eventually results in the lack of professional management. In small, family-run companies that are usually managed by the founder who also works at the front desk, there is no space for a manager post. In other words, it is more difficult to persuade small firm owners to start cooperation as they might have not enough professional management knowledge to properly understand the benefit they may derive from it. SMEs also often reflect the personality of the founder (Keasey and Watson, 1993), and because of this, SMEs are often characterised by a strong will to survive. Running one's own small company is also often regarded as the founder's way to be independent. This may result in creating the so-called fortress mentality (Lynch, 2000) and hence an obstacle to cooperation (Simpson and Bretherton, 2004, p. 112). SMEs are also much more vulnerable to bankruptcy and new companies are frequently created (Wanhill, 2000), so the list of companies that are part of the destination network is often changed. This is a serious difficulty in establishing long-term sustainable relations between companies in a destination, which is suggested by the NT.

\subsection{Differences between particular destination types}

It is difficult to establish common rules of how to implement any competitive advantage paradigm in the tourism destinations field as destinations differ from one another significantly. Instead one should look for paradigms that are proper for particular types of destinations. The statement about the predominance of SMEs would not be relevant to some destinations, e.g. large cities. Instead, the problem of cooperation between hotels that are part of worldwide hotel chains may appear. Different destinations offer different products and are present in different markets. So, it is very likely that ideas that are effective in a 
particular destination might not work in another. Different destinations might need different modifications of the NT when implemented.

The concept that examines the community and the corporate models of destinations is an example of the most popular differences between destinations (Flagestad and Hope, 2001; Beritelli, Bieger and Leasser, 2007). The community model represents a situation which is common in most European tourism destinations where multiple smallsized, mostly local companies, are involved in tourism product development. Additionally, the role and support of the local government are relatively high. In contrast, the corporate model is rather a North American destinations style model with unquestionable leadership of large, often external corporations in destination development. The structure of management here is more similar to company management and is more integrated, hierarchical and centralised than the community model destinations (Flagestad, 2002). Beritelli, Bieger and Leasser (2007, p. 97) claim that the NT is the proper approach for community model destinations, while the dyadic resource dependency theory explains correctly the relations within the corporate model destinations. It might be questionable, however, if, even in large companydominated destinations where other companies play the roles of a leader's satellites, relationships between those satellites do not exist or do not play an important role in destination competitiveness. Still, even if this is accepted, it is likely that the dyadic relationships between the focal company and individual satellite firms would be mutually interrelated (Wang and Xiang, 2007, p. 76). Then, instead of the simple dyadic perspective, Jarillo's (1998) concept of a network within the hub firm, would better match the corporate model of destinations. But this argument does not change the fact that management in the corporate model destinations and the community model destinations should involve different NT approaches, as Jarillo's hub firm network does not match the community model.

Finally, destinations that attract different tourism markets have to cope with the different features they have and with different customers' behaviours which might require different methods of organising the local tourism network. This could include long-haul versus short break holidays, for example, or leisure versus business tourism destinations.

\subsection{Difficulties in setting clear borders between destinations}

One of the important arguments raised by IR supporters is the difficulty in setting exact borders between companies, with outsourcing and resource dependencies and activities crossing companies' borders. Instead, we should analyse the competitiveness of networks. It is surprising then that the IR researchers might repeat the same mistake, but on the level of a network. In many cases the whole network approach (Provan, Fish and Sydow, 2007; McLeod, 2014), which is very suitablefor a tourism destination analysis, resultsin regarding a network of collaborating entities as well separated from the environment closed system, that acts on the market in a similar way to Porter's (1980) value system. This approach is not suitable for tourism destinations analysis for at least three reasons (Żemła, 2014, p. 243). Firstly, the hierarchical structure of tourism destinations must be considered. A single destination may consist of many smaller destinations. Several communities form a tourism region, just as several regions comprise a country, etc. Actions on different markets require different definitions of the destination. The most obvious reason for this is the different views of tourism destinations that visitors have, which is usually, but not always, a result of the distance between a visitor's residence place and the destination. For people travelling from nearby, the destination can be a single settlement, while for tourists from overseas markets this is usually the whole country. This links the neighbouring destinations in coopetition (Bengtsson and Kock, 2000) ties in the same manner as tourism companies are connected within a single destination. Actions on many markets require the destination's ability to cooperate with the neighbour in one market, while competing with it in another. What makes this relation even stronger is the fact that the destinations set with regard to a supply side perspective, does not represent the perspectives of a particular visitor. While the visitors stay in one destination, they also often visit neighbouring areas, which means that having a neighbouring destination with a very competitive offer might not necessarily be just a threat but it may also be an opportunity for the destination. As a result, the need of both intra- and inter-destination cooperation is stressed (Fyall, Garrod and Wang, 2012; Żemła, 2014).

Secondly, many tourism entities, including both companies and localities, might simultaneously participate in more than one destination, which is the result of the fact that destinations are formed using different criteria in setting the borders. This makes the problem of competition and cooperation between destinations even more complex.

Finally, a destination's product is formed not only by internal entities, but also the external stakeholders' role has to be acknowledged. Some of them, like investors, might be treated as permanently connected with a destination; however, there are firms who cooperate with a destination's product creation and marketing only accidentally. This might include tour-operators and companies like breweries, sport equipment producers or others, who conduct common promotional campaigns with the destination. In some cases, they may cooperate with the destination as whole, but they also collaborate with particular companies within one destination (Żemła, 2010b).

\section{Conclusions}

It may also be clearly seen that current research results in creating more complex and complicated methods of interpreting the term. Among them, the networking approach is one of the most popular in the $21^{\text {st }}$ century. Over the past two decades, a growing number of studies has been published which focus on the role of networks in tourism. Tourism destinations are a special kind of network and cooperation processes are crucial for them to succeed. Once researchers and practitioners accept the above statement, they can start looking for the best approach to create sustainable competitive advantage in the tourism market within NT theory. The differences between traditionally understood company networks and tourism destinations as presented here, however, make NT difficult to implement and make it full of traps.

Unfortunately, the contemporary literature does not offer any detailed description of how to implement NT properly. Van der Zee and Vanneste (2015) state that the promising theoretical claims of the potential benefits of networked collaboration in tourist destinations are supported by empirical evidence only to a limited extent. According to these authors, there are two explanations for the lack of empirically proven benefits. First, progress is hampered by failing to integrate the field of tourism network studies, as there are different sub-fields of research. These sub-fields 
apply different approaches towards tourism networks, from both theoretical and methodological perspectives. There is little cross-fertilisation between the sub-fields and integrative studies are still scarce. Secondly, while many studies show interesting and promising findings, the field would make greater progress if researchers more systematically reflected on the relationship between network goals and projected outcomes, and on the most suitable methodology to test the effects of the required network development in a comprehensive way (Van der Zee and Vanneste, 2015, p. 46).

While keeping in mind that networking theory stands for a very wide and diversified idea used by representatives of different sciences to analyse really different phenomena, one might be surprised that most authors who search for inspiration in NT to carry out tourism destination analysis, find it in only one approach. Regarding a destination as a unit of market competition focuses the attention of researchers on problems of efficiency and management and, as a consequence, on implementing mainly the achievements of business network analysis. According to the broad division outlined by Newman (2003, p. 168), however, business networks are only one kind (other examples might be the Internet, neural networks, metabolic networks, food webs, distribution networks such as blood vessels or postal delivery routes, networks of citations between papers, and many others) of many different networks present in the contemporary world which are analysed using networking methods. These networks are the subject of interest of different scientists including engineering scientists, physicians, mathematicians, geographers, and sociologists. To some extent, once the present review of the approaches using NT in the literature devoted to the topic of tourism was undertaken, the achievements of business networks analysis formed the principal outcome. We are aware of this limitation and as one of the important directions for future studies, it is to be pointed out that the scope of analysis of tourism destinations must be widened using the methods developed in other approaches to network analysis.

This paper points out some major problems in implementing NT in tourism destinations analysis; however, further research should also include the search for the best solution and, at the same time, the constraints presented here must be respected. These constraints can also be seen as consequences of a more general problem than the problems themselves. This more general problem is the too direct implementation of business networks theory. As presented here, tourism destinations perceived as networks of actors are very specific and they have some features which might not be observed in business networks of other kinds, even those in tourism, like the airlines alliances. That is why this paper is a call for a general theory of tourism destinations networks, which should be created on the bases of contemporary business networks theory but supplemented as well by the achievements of the analysis of networks of different types, as well as by contributions from different sciences dealing with the topic. This seems to be a very challenging task and requires the joint efforts of many researchers and time.

Another problem is associated with the fact that as the basic theory, NT is diversified and parts of it are not fully coherent - they combine many different approaches, and they also contain their consequences in the tourism area. Future research, however, should be more focused on specific features of tourism destinations instead of looking for other sub-theories of NT which would be more promising if adapted. A general theory of destination networking is missing and filling this gap should be regarded as a long-term target for researchers involved in this topic. Otherwise, the networking approach is going to be just another promising concept with no sound explanations, and it will be used only in research on small fragments of the complex issue of destinations.

Finally, one should remember that while the networking approach is nowadays perceived as one of the most promising approaches to tourism destinations, it still cannot be perceived as the only possible approach. On the contrary, having implemented the very idea into tourism research, the achievements of other approaches presented in the first part of this paper can be integrated into it. Also, the network perspective can be very useful for researchers using other approaches, as it helps in perceiving the details of destination structure. For example, the networking perspective might be a good solution for analysing sociological issues in destinations and the economic benefits of tourism development, as well as in examining management structures and processes, in particular planning.

\section{References:}

ALBRECHT, J. N. (2013): Networking for sustainable tourism - Towards a research agenda. Journal of Sustainable Tourism, 21(5): 639-657.

AMIN, A., THRIFT, N. (2002): Cities: reimagining the urban. Cambridge, Polity Press.

ASHEIM, B., COOKE, P., MARTIN, R. (2008): Clusters and regional development: Critical reflections and explorations. Economic Geography, 84(1): 109-112.

BAGGIO, R., SCOTT, N., COOPER, C. (2010a): Improving tourism destination governance: a complexity science approach. Tourism Review 65(4): 51-60.

BAGGIO, R., SCOTT, N., COOPER, C. (2010 b): Network science: A review focused on tourism. Annals of Tourism Research, 37(3): 802-827.

BARRINGER, B. R., HARRISON, J. S. (2000): Walking a tightrope: Creating value through interorganizational relationships. Journal of Management, 26(3): 367-403.

BEAUMONT, N., DREDGE, D. (2010): Local tourism governance: A comparison of three network approaches. Journal of Sustainable Tourism, 18(1): 7-28.

BECATTINI, G. (2002a): Industrial sectors and industrial districts: Tools for industrial analysis. European planning studies, 10(4): 483-493.

BECATTINI, G. (2002b): From Marshall's to the Italian "Industrial districts". A brief critical reconstruction. In: Curzio, A.Q., Fortis M. [eds.]: Complexity and Industrial Clusters (pp. 83-106). Physica-Verlag HD.

BENGTSSON, M., KOCK, M. (2000): "Coopetition" in business networks-To cooperate and compete simultaneously. Industrial Marketing Management, 29(5): 411-426.

BERITELLI, P., BIEGER, T., LAESSER, C. (2007): Destination governance: using corporate governance theories as a foundation for effective destination management, Journal of Travel Research 46(1): 96-107.

BIEGER, T. (1998). Reengineering destination marketing. Tourism Review, 53(3): 4-17.

BJORK, P., VIRTANEN, H. (2005): What tourism project managers need to know about co-operation facilitators. Scandinavian Journal of Hospitality and Tourism 5(3): 212-230. 
BORDAS, E. (1994). Competitiveness of tourist destinations in long distance market. Tourism Review, 49(3): 3-9.

BORNHORST, T., RITCHIE, J. B. R., SHEEHAN, L. (2010): Determinants of tourism success for DMOs \& destinations: An empirical examination of stakeholders perspectives. Tourism Management, 31(5): 572-589.

BUHALIS, D. (2000): Marketing the competitive destination of the future. Tourism Management, 21(1): 97-116.

BURKART, A. J., MEDLIK, S. (1974): Tourism. Past, present and future. London, Heinemann.

CAPONE, F., BOIX, R. (2003): Sources of competitiveness in tourist local systems: An application to Italy. Proceedings of $45^{\text {th }}$ Congress of the European Regional Science Association, Amsterdam, 23-27.10.2003: 23-27.

CHROMÝ, P., KUČEROVÁ, S., KUČERA, Z. (2009): Regional identity, contemporary and historical regions and the issue of relict borders: the case of Czechia. Region and Regionalism, 9(2): 9-19.

COHEN, E., COHEN, S.A. (2012), Current sociological theories and issues in tourism. Annals of Tourism Research, 39(4): 2177-2202.

CORŇ, G., GRANDINETTI, R. (2001): Industrial district responses to the network economy: vertical integration versus pluralist global exploration. Human Systems Management, 20(3): 189-199.

D‘ANGELLA, F., GO F. M. (2009): Tale of two cities' collaborative tourism marketing: Towards a theory of destination stakeholder assessment. Tourism Management, 30(3): 429-440.

D'ANGELLA F., SAINAGHI R. (2004): Building competitive advantage of district firms: the role of the network and the company. In: Keller P., Bieger, T. [eds.]: The future of small and medium sized enterprises in tourism (pp. 35-53). St. Gallen, AIEST.

DA CUNHA, S. K., DA CUNHA, J. C. (2005): Tourism cluster competitiveness and sustainability: proposal for systematic model to measure the impact of tourism local development. Brazilian Administration Review, 2(2): 47-62.

DARWENT, D. F. (1969): Growth poles and growth centers in regional planning: a review. Environment and Planning, 1: $5-11$.

DAWES, J., ROMANIUK, J., MANSFIELD, A. (2008): Generalized patterns in competition among tourism destinations. International Journal of Culture, Tourism and Hospitality Research, 3(1): 33-53.

DOZ, Y. L., HAMMEL, G. (1998): Alliance advantage. Boston, Harvard Business School Press.

ELMAZI, L., PJERO, E., BAZINI, E. (2006): Tourist destination as a business system and the application of marketing in destination management. Paper read at International Conference of Trends, Impacts, Policies and Tourism Development. Heraklion, Greece 15-18.06 2006.

ENRIGHT, M. J. (2003): Regional clusters: what we know and what we should know. In: Bröcker, J., Dohse, D., Soltwedel, R. [eds.]: Innovation clusters and interregional competition (pp. 99-129). Berlin: Springer.

ENRIGHT, M. J., ROBERTS, B. H. (2001): Regional clustering in Australia. Australian Journal of Management, 23 (1 Suppl): 65-85.
EWING, G., HAIDER, W. (2000): Estimating what affects tourist destination choice (pp. 35-58). In: Pizam, A., Mansfeld, Y. [eds.]: Consumer behavior in travel and tourism. New York.

FENG, W. H., MIAO, C. H. (2009). A review of researches on tourism cluster at home and abroad. Human Geography, 2009(1): 8-18.

FLAGESTAD, A. (2002): Strategic success and organisational structure in winter sports destinations. A multiple stakeholder approach to measuring organizational performance in Scandinavian and Swiss case studies. Östersund, ETOUR.

FLAGESTAD, A., HOPE, C. A. (2001); Strategic success in winter sports destinations: a sustainable value creation perspective. Tourism Management, 22(5): 445-461.

FRAMKE, W. (2001): The 'destination': A problematic concept. Paper presented at $10^{\text {th }}$ Nordic Tourism Research Conference, Vasa 19-20.10.2001.

FYALL, A., GARROD, B. (2005): Tourism marketing. A collaborative approach. Clevedon, Channel View Publ.

FYALL, A., GARROD, B., WANG, Y. (2012): Destination collaboration: A critical review of theoretical approaches to a multi-dimensional phenomenon. Journal of Destination Marketing \& Management, 1(1): 10-26.

GALASKIEWICZ J. (1985): Interorganizational relations. Annual Review of Sociology, 11: 281-304.

GALASKIEWICZ, J., WASSERMANN, S. (1994): Introduction: Advances in the social and behavioral science from social network analysis. In: Wassermann, S., Galaskiewicz, J. [eds.]: Advances in social network analysis. Newbury Park, Sage.

GNOTH, J. (2004): Strengthening tourism SME brands. In: Fueglistaller M., Volery, T., Weber, W. [eds]: Value creation in entrepreneurship and SMEs (pp. 261-270). St. Gallen, University of St. Gallen.

GO, F. M., APPELMAN, J. (2001): Achieving global competitiveness in SMEs by building trust in interfirm alliances. In: Wahab, S., Cooper, C. [eds.]: Tourism in the Age of Globalization (pp. 183-197). London, Routledge.

GOELDNER, C. R., RITCHIE, J. R. B. (2003): Tourism: principles, practices, philosophies. Hoboken, Willey.

GONÇALVES, V. F. C., ÁGUAS, P. M. R. (1997): The concept of life cycle: An application to the tourism product. Journal of Travel Research 35(4): 12-21.

GUINET, J. (1999): Introduction to boosting innovation the cluster approach. In: Guinet, J. [ed.]: Boosting Innovation the Cluster Approach (pp. 7-8). Paris: OECD.

GULATI, R., NOHRIA, N., ZAHEER, A. (2000): Strategic networks. Strategic Management Journal, 21(3): 203-215.

HALL, C. M. (2005). Tourism: Rethinking the social science of mobility. Harlow, Prentice-Hall.

HANKINSON, G. (2004): Relational network brands: Towards a conceptual model of place brands. Journal of Vacation Marketing, 10(2): 109-121.

HASSAN, S. (2000): Determinants of market competitiveness in an environmentally sustainable tourism industry. Journal of Travel Research, 38(3): 239-245.

HAWKINS, D.E. (2004): A protected areas ecotourism competitive cluster approach to catalyse biodiversity 
conservation and economic growth in Bulgaria. Journal of Sustainable Tourism, 12(3): 219-244.

HILL, E. W., BRENNAN, J. F. (2000): A methodology for identifying the drivers of industrial clusters: the foundation of regional competitive advantage. Economic Development Quarterly, 14(1): 65-96.

HJALAGER, A. M. (2000): Tourism destinations and the concept of industrial districts. Tourism and Hospitality Research, 2(3): 199-213.

HOSANY, S., EKINCI, Y., UYSAL, M. (2007): Destination image and destination personality. International Journal of Culture, Tourism and Hospitality, 1(1): 62-81.

HOSPERS, G. J., BEUGELSDIJK, S. (2002): Regional cluster policies: Learning by comparing? KYKLOS, 55(3): 381-402.

HU, Y., RITCHIE, J. B. (1993): Measuring destination attractiveness: A contextual approach. Journal of Travel Research, 32(2): 25-34.

IZADI, R., SABERI, H. (2015): Comparative study of selecting tourist destinations abroad: A case study of Antalya and Dubai cities. Journal of Sustainable Development, 8(9): 147-156.

JACKSON, J., MURPHY, P. (2006): Clusters in regional tourism: An Australian case. Annals of Tourism Research, 33(4): 1018-1035.

JARILLO, J. C. (1998): On strategic networks. Journal of Strategic Management 9(1): 31-41.

JONES, E., HAVEN-TANG, C. (2005): Tourism SMEs, service quality and destination competitiveness. In: Jones, E., Haven-Tang, C. [eds.]: Tourism SMEs, service quality and destination competitiveness (pp. 1-22) Wallingford, CABI Publishing.

KEASEY, K., WATSON, R. (1993): Small firm management. Oxford, Blackwell.

KOESTANTIA, T., NURYANTI, W., SUWARNO, N., PRAYITNO, B., FEMINA, D. (2014): The distribution pattern of creative industries and the spatial system of tourist destinations in Indonesia: The case of Bandung. International Journal of Architecture and Design, 25(2): 1140-1148.

KONEČNIK, M., RUZZIER, M. (2006): The influence of previous visitation on customer's evaluation of a tourism destination. Managing Global Transition, 4(2): 145-165.

KOZAK M. (2004): Destination benchmarking. Concepts, practises and operations. Wallingford, CABI Publishing.

LAZZERETTI, L., PETRILLO, C. S. (2006): Tourism local systems and networking. Oxford, Elsevier.

LEIPER, N. (1990): Tourist attraction system. Annals of Tourism Research, 17(3): 367-384.

LEIPER, N. (2004): Tourism management ( $3^{\text {rd }}$ ed.). Frenchs Forest, Pearson Education, Australia.

LYNCH, P. A. (2000): Networking in the homestay sector. Service Industries Journal, 20(3): 95-116.

MARKOVÁ, B. (2014): Creative clusters in the Czech Republic - strategy for local development or fashionable concept? Moravian Geographical Reports, 22(1): 44-50.

MARIUTTI, F. G., GIRALDI, J. D. M. E., CRESCITELLI, E. (2013): The image of Brazil as a tourism destination: an exploratory study of the American market. International Journal of Business Administration, 4(1): 13-22.
MARSHALL, A, (1898): Principles of Economics. New York, McMillan \& Co.

MARTIN, R., SUNLEY, P. (2003): Deconstructing clusters: chaotic concept or policy panacea? Journal of Economic Geography, 3(1): 5-35.

MASKELL, P. (2001): Towards a knowledge-based theory of the geographical cluster. Industrial and corporate change, 10(4): 921-943.

MCLEOD, M. (2014): Analysing inter-business knowledge sharing in the tourism sector. In: McLeod, M., Vaughan, R. [eds.]: Knowledge networks and tourism (pp. 143157). Abingdon: Routledge.

MILL, R. C., MORRISON, M. (1985): The tourism system. New Jersey, Prentice Hall.

MÖLLER, K., SVAHN, S. (2003): Managing strategic nets. A capability perspective. Marketing Theory 3(2): 209-234.

MORGAN, N. J., PRITCHARD, A., PIGGOTT, R. (2002): New Zealand, $100 \%$ Pure. The creation of a powerful niche destination brand. Journal of Brand Management, 9(4-5): 335-354.

MORGAN, N., PRITCHARD, A., PRIDE, R. (2003): Destination branding. Creating the Unique destination proposition. Oxford, Butterworth Heinemann.

MOTTIAR, Z., RYAN, T. (2006): The Role of SMEs in Tourism Development: an Industrial District Approach Applied to Killarney, Ireland. In: Thomas, R., Augustyn, M. [eds.]: Tourism in the New Europe: perspectives on SME policies and practices (pp. 63-78), London/New York, Routledge.

MURPHY, P. (1985): Tourism. A community approach. London, Routledge.

NEWMAN, M. E. J. (2003): The structure and function of complex networks. SIAM Review, 45(2): 167-256.

NICHOLLS, W. (2009): Place, networks, space: theorising the geographies of social movements. Transactions of the Institute of British Geographers, 34(1): 78-93.

NORDIN, S. (2003): Tourism clustering \& innovation - path to economic growth \& development. Östersund: ETOUR.

NORDIN, S., SVENSSON, B. (2007): Innovative destination governance: The Swedish ski resort of Are. Entrepreneurship and Innovation, 8(1): 53-66.

PAGET, E., DIMANCHE, F., MOUNET, J. P. (2010): A tourism innovation case: An actor-network approach. Annals of Tourism Research, 37(3): 828-847.

PAASI, A. (2001): Europe as a social process and discourse: consideration of place, boundaries and identity. European Urban and Regional Studies, 8(1): 7-28.

PECHLANER H. (1999): The competitiveness of Alpine destinations between market pressure and problems of adoption. Tourism, 47(4): 332-343.

PECHLANER, H., ABFALTER, D., RAICH, F. (2002): Crossborder destination management systems in the Alpine region-The role of knowledge networks on the example of AlpNet, Journal of Quality Assurance in Hospitality \& Tourism 3(3/4): 89-107.

PIKE, S., PAGE, S. (2014): Destination Marketing Organizations and destination marketing: A narrative analysis of the literature. Tourism Management, 41(1): 202-227.

PORTER, M. E. (1990): Competitive advantage of nations. New York, Free Press. 
PORTER, M. E. (1998) On competition. Boston, Harvard Business School Press.

PROVAN, K. G., FISH, A., SYDOW, J. (2007): Interorganizational networks at the network level: A review of the empirical literature on whole networks. Journal of Management, 33(3): 479-516.

PYKE, F., BECATTINI, G., SENGENBERGER, W. (1992): Industrial districts and inter-firm co-operation in Italy. International Institute for Labour Studies: Geneva.

RHODES, R. A. W. (1997): Understanding governance. Policy networks, governance, reflexivity and accountability. Buckingham, Open University Press.

RUHANEN, L., SCOTT, N., RITCHIE, B., TKACZYNSKI A. (2010): Governance: a review and synthesis of the literature. Tourism Review, 65(4): 4-16.

SCOTT, A. J. (1983): Location and linkage systems: a survey and reassessment. The Annals of Regional Science, 17(1): 1-39.

SCOTT, A. J. (1986): Industrial organisation and location: Division of labour, the firm, and spatial process. Economic Geography, 63(3): 215-231.

SCOTT, A. J., GAROFOLI, G. (2007): The regional question in economic development. In: Scott, A. J., Garofoli, G. [eds]: Development on the ground: Clusters, networks and regions in emerging economies (pp. 3-22). London: Routledge.

SCOTT, A. J., STORPER, M. (2003): Regions, globalization, development. Regional Studies, 37(6-7): 579-593.

SCOTT, N., BAGGIO, R., COOPER, C. (2008): Network analysis and tourism: from theory to practice. Clevedon, Channel View Publication.

SCOTT, N., COOPER, C., BAGGIO, R. (2008): Destination networks: four Australian cases. Annals of Tourism Research, 35(1): 169-188.

SEMIAN, M. (2012): Searching for the territorial shape of a region in regional consciousness: the Český Ráj (Bohemian Paradise), Czech Republic. Moravian Geographical Reports, 20(2): 25-35.

SEATON, A. V., BENNETT, M. M. (1997): Marketing tourism products. London, Thomson Business Press.

SFORZI, F. (1989): The geography of industrial districts in Italy, In: Goodman, E., Bamford, J., Saynor, P. [eds.]: Small Firms and Industrial Districts in Italy, (pp. 153173). London: Routledge.

SIMPSON, K., BRETHERTON, P. (2004): Co-operative business practices in the competitive leisure destination: lessons from the wine tourism industry in New Zealand. Managing Leisure 9(2): 111-123.

TALLMAN, S., JENKINS, M., HENRY, N., PINCH, S. (2004): Knowledge, clusters, and competitive advantage. Academy of management review, 29(2): 258-271.

TAN, W. K., LIU, W. C., HU, Y. N. (2013): Finding the crucial factors for sustainable development of rural-based tourist destinations: using Nanzhuang, Taiwan as a case study. Service Busigness, 7(4): 623-640.
VAJČNEROVÁ, I., ŠÁCHA, J., RYGLOVÁ, K. (2013): Using the principal component analysis for evaluating the quality of a tourist destination. Acta Universitatis Agriculturae et Silviculturae Mendelianae Brunensis, 60(2): 449-458.

WANG, Y., XIANG, Z. (2007): Toward a theoretical framework of collaborative marketing. Journal of Travel Research, 46(1): 75-85.

WANHILL, S. (2000): Small and medium tourism enterprises. Annals of Tourism Research, 27(1): 132-147.

WEIERMAIR K., STEINHAUSER, C. (2003): New tourism clusters in the field of sports and health: The case of Alpine wellness. Paper presented at $12^{\text {th }}$ International Tourism and Leisure Symposium, Barcelona, April 2003.

WOODS, M., DEEGAN, J. (2003): A warm welcome for destination quality brand: the example of Pays Cathare Region. International Journal of Tourism Research 5(4): 269-282.

WOODSIDE A. G., LYSONSKI S. (1989): A general model of travel destination choice. Journal of Travel Research, 27(4): 8-14.

WOODISDE, A. G., SHERRELL, D. (1977): Traveler evoked, inept and inert sets of vacation destinations. Journal of Travel Research, 16(1): 14-18.

WTO (2002). Thinktank. World Tourism Organisation [online]. Available at: http://www.world-tourism.org/ education/menu.html

ZACH, F., RACHERLA, P. (2011): Assessing the value of collaborations in tourism networks: A case study of Elkhart County, Indiana. Journal of Travel \& Tourism Marketing, 28(1): 97-110.

VAN DER ZEE, E., VANNESTE, D. (2015): Tourism networks unravelled; a review of the literature on networks in tourism management studies. Tourism Management Perspectives, 15: 46-56.

VON FRIEDRICHS GRÄNGSJÖ, Y. (2007): Networking tourism entrepreneurs and the role of social capital. Paper presented at International Conference Advances in Tourism Marketing. Destination and Event Marketing: Managing Networks, Valencia 10-12.09.2007.

ZMYŚLONY P. (2009): City for half-price: towards the collaborative price decision-making in a tourism destination. In: Fyall, A., Kozak, M., Andreu, L., Gnoth, J., Lebe, S. S. [eds.]: $3^{\text {rd }}$ Advances in Tourism Marketing Conference. Advances in Tourism Marketing Conference 2009. Marketing Innovations for Sustainable Destinations: Operations, Interactions, Experiences. Bournemouth, Bournemouth University.

ŻEMŁA, M. (2010a): Destination brand licensing. In: Kozak, M., Gnoth, J., Andreu, L. L. A. [eds.]: Advances in tourism destination marketing. Managing networks (88-98). Abingdon, Routledge.

ŻEMŁA, M. (2010b): Destination competitiveness and interorganizational relations competitiveness paradigm. Challenges of application. Service Management, 5: 249-263.

ŻEMŁA, M. (2014). Inter-destination cooperation: Forms, facilitators and inhibitors-The case of Poland. Journal of Destination Marketing \& Management, 3(4): 241-252. 